\title{
REINTERPRETATION OF HIJAB CONCEPT IN THE VIEW OF MURTADHA MUTAHHARI
}

\author{
Nurul Khair \\ Sekolah Tinggi Filsafat Islam (STFI) Sadra Jakarta \\ nurulkhair97@gmail.com
}

\begin{abstract}
In the view of Millennial society, Hijab was better known as fashion for woman to look beautiful. It's proven by the presence of so many tutorials wearing Hijab with various models showed on Youtube. Those tutorials influenced women views that to make them look completely enchanting they should wear Hijab. As the consequence, Hijab what must be believed to be an obligation and the guidance of the Shari'a, it's even understood by women as a form of need and desire only, and it's especially just to attract man attentions. Former times, Hijab was understood by people as a symbol of glory and a form of the obedience of a woman to God. But, now, due to misunderstanding of the meaning and the essence of Hijab, it's misused by women in this Millennial era. To solve this problem, it's required a philosophical study. This study is expected to be one way to refine meaning of the essence of Hijab. To look further, we can study some views of Sayid Murtadha Muthahhari. He was one of contemporary Iranian philosophers who refined the essence of Hijab. In Murtadha Mutahhari philosophical views, he offered to us four meaning of the essence of Hijab, those were the first was psychological tranquility, the second was strengthen the relationship of husband and wife, the third was the glory and honor of women, and the fourth was strengthen of the society. In another hand, he also offered to us three reasons that why women must wear Hijab. It's economic reasons, social reason, and ethical reason. This Study is trying to refine and inform the meaning of the essence of hijab to Moslem society through Murtadha Mutahhari philosophical view.
\end{abstract}

Keywords: Hijab, Essence, Meaning, Murtadha Mutahhari.

\section{Introduction}

Islamic teachings is guidance for mankind to realize the life of grace. Realizing the life of grace required a variety of social practices between individuals. Islamic ideology has rules that govern the lives of mankind, in order to realize the life of grace, including happiness, progress, welfare, benefit in the social sphere ${ }^{1}$. 
One of the Islamic rules governing the life or interaction of individuals is hijab. Hijab in Islamic perspective is one of the important issues, until the Qur'an mentions and discusses the problematics of hijab ${ }^{2}$. As explained in sura al-Ahzab verse 59, means:

"O Prophet! Tell your wives and your daughters and believing women that they will stretch out their hijabs. Thus, they will be more recognizable so they are not disturbed. And Allah is Forgiving and Merciful". (Qs. AlAhzab / 33: 59)

Explicitly it is known that the above paragraphs, using the editorial order to wear the hijab to the believing women with the goal of limiting the association of men and women ${ }^{3}$. Quraish Shihab interpreted the above paragraphs through nuzul asbabun approach. In his interpretation, he states that the Muslims have known hijab's usage, this is reinforced "in order for them to stretch their hijab". However, Muslims do not wear the hijab as they should, resulting in them being victims of sexuality. So, the word "Thus, they will be more recognizable so they are not disturbed. And Allah is Forgiving and Merciful' is a practical implication in extending the hijab 4 . Based on the surah al-Ahzab: 59 it is known that Islam is very respectful and preserves the sanctity of women from various sexual harassment which often gives negative effects to a woman.

Hijabs in Islamic views have similarities from the past traditions of society, such as the traditions of ancient Egyptians and the Byzantines (both cultures existed before the existence of Islam) ${ }^{5}$. In the perspective of the ancient Egyptian tradition, hijab is understood as a form of gender equality. As Jean Vercounter discloses that the hijab gives every woman a privilege to gain their egalitarian rights and conditions, especially in the worship of the gods ${ }^{6}$. In other cultures, such as the Byzantine culture, it is known that hijab is used to avoid the various forms of exploitation of women ${ }^{7}$. Hijab is used to control the lust of men who always see the sexuality of women.

The authors views, from the various explanations above, can be seen that the concept of hijab in the previous view of society, both theoretically and practically has an important role in maintaining the sanctity and rights of women. The phenomenon of ancient people, very different, when compared with the phenomenon of millennial society who understand and practice hijab in his life ${ }^{8}$.

Hijab in the view of millennial society more understood as fashion in beautifying itself, this can be proved by the community hijabers and tutorials using hijab with various models. As a result, many women 
beautify themselves by using hijab. This understanding is influenced by the development of fashion moslem in Indonesia9. The development of fashion moslem can be seen with many industries that produce hijab style creations, so the use of hijab not be a heavy consideration for the Muslim in deciding the hijab ${ }^{10}$. Meaning of hijab as fashion resulted in distortion of hijab concept in millennial society understanding, hijab in the previous society view has the meaning of sacredness and form of piety for the Muslimah, but different in view of millennial society which mean as mere fashion. On the other hand, hijab has the function of keeping the Muslim holiness from sexual acts, but the hijab in millennial society's view aims to beautify themselves and captivate the opposite sex, thus implying the existence of sexual acts. This also becomes a serious problematic and discourse in the this century.

To solve the above problem, need to study philosophy study to restore the meaning and essence of hijab as it should. Murtadha Mutahhari is one of contemporary century philosophers, present in his philosophical thought which aims to restore the meaning and essence of hijab. In his philosophical thought, Murtadha Mutahhari offers four essences of hijab, namely the psychological tranquility, strengthening the relationship of husband and wife, glory and honor of women, and a strong society. The explanation of the four hijab essences in the view of Mutahhari is believed to restore the meaning of hijab that has been distorted in the millenial era.

On the other hand, to restore the essence and meaning of hijab, an individual must know the ground or reason applied to hijab in a religious, cultural, and social context. In discussing these issues, Mutahhari discuss through the ethical, social, and economic spaces. These three reasons are examined through a philosophical approach, thus presenting an integrative (universal) and objective offer that is acceptable in various contexts of life ${ }^{11}$. By looking at Murtadha Mutahhari's offerings as a fundamental reason, the researchers took the theme of "Reinterpretation of Hijab Concept in the View Murtadha Mutahhari", based on two main works, On the Islamic Hijab and The Islamic Modest Dress.

\section{Meaning of Hijab in Various Views}

Etymologically, the word hijab comes from the Arabic гجاب which means curtain or dividing wall ${ }^{12}$. Ibn Khaldun in his work entitled alMuqadimmah using the word hijab as distance and separation between society and government ${ }^{13}$. In contrast to Ibn Khaldun's view, Ibn Marzah 
in the Lisan al-Arab book defines the word hijab as a barrier or a separator covering something, so that something is not visible ${ }^{14}$. A hijab woman means a woman who covers herself with some kind of object that becomes a barrier until she is invisible. Ibn Marzah's view was clarified by Ahmad Suhendra, as NU Yogjakarta's Board of Directors in his research, that the hijab is the separator and barrier between women and men. It aims to avoid harassment of women ${ }^{15}$.

As for terminology, hijab means reducing and restricting something from something else to the purpose of covering something out of sight ${ }^{16}$. In the fuqaha perspective, hijab is replaced by the word satr. Fuqaha view that the word satr has the proper meaning in studying Islamic rituals, such as marriage ${ }^{17}$. Murtadha Mutahhari sees that fuqaha is wrong in understanding the concept of hijab. In his view, he states that if the hijab is conceived as a cover, then it describes a woman behind a curtain (cover). This led to the view that Islam imprisoned women ${ }^{18}$. Therefore, Murtadha Mutahhari considers that the hijab should be understood as an immaterial restriction, because something which is bounded immaterial, ie desire ${ }^{19}$. The views of Murtadha Mutahhari were also confirmed through the Qur'anic verses, as he relied on surah al-Ahzab verse 59, an-Nur verses 30-31, and al-Ahzab verse 53.

"Tell the believing men to reduce [some] of their vision and guard their private parts. That is purer for them. Indeed, Allah is Acquainted with what they do. And tell the believing women to reduce [some] of their vision and guard their private parts and not expose their adornment except that which [necessarily] appears thereof and to wrap [a portion of] their headcovers over their chests..." (Qs. An-Nur/24:30-31)

Both verses above illustrate that men and women must maintain their vision and control their genitals from actions that cause desire ${ }^{20}$. However, the question arises in understanding the above two verses. How can one withstand his vision and control the genitals from actions that lead to sexuality between men and women? Murtadha Motahhari in his philosophical view of the problematic answer, by Qs. Al-Ahzab/33:53;

"And when you ask (his wife) for something, ask them from behind a partition...." (Qs. Al-Ahzab/33:53)

Verse 53 in sura al-Ahzab gives the answer that men and women should keep their distance by displaying a veil or a dividing wall between the two. If a man wants to meet a woman, he must create a dividing wall between man and woman ${ }^{21}$. The hijab command is applied to the Muslims, as described in al-Ahzab / 33: 59; 
"O Prophet, tell your wives and your daughters and the women of the believers to bring down over themselves (part) of their outer garments. That is more suitable that they will be known and not be abused. And ever is Allah Forgiving and Merciful". (Qs. Al-Ahzab/33:59)

Extending hijab means distancing the relationships of men and women, so a woman avoids interference from the opposite sex. The command of the use of hijab for women, girls, and wives is an award given by Islam for the sanctity of women ${ }^{22}$. Islam greatly upholds and glorifies women, as explained by the four verses above ${ }^{23}$.

Through the philosophical view of Murtadha Mutahhari, it can be seen the relation of the above four verses. But it is important to note that the philosophical explanation of Murtadha Mutahhari has something in common with the traditions of ancient society, such as the traditions of ancient Egyptian society and the medieval Byzantine tradition. In the ancient Egyptian tradition, hijab is understood as restricting the behavior of men and women. Because women always get mistreated through the deprivation of their rights of life, such as religious rights, ethical rights, family rights, etc. which imply the absence of a process of gender equality and the glorification of women ${ }^{24}$.

As Jean Vercoutter puts it in his article New Kingdom, that "Absolute equality between men and women is so obvious. There is no doubt that this understanding of equality derives from the common belief (hijab) that privileges Egyptian women". Vercoutter's view was reinforced by Arvind Sharma in his work Today Today Woman in World Religion, that women get their rights, such as the enactment of dendan pay and return the dowry, in the case of a one-sided divorce done by the husband, the marriage agreement which implies the absence of polygamy, and family rights. These rights rest on a common belief that implies equality between men and women ${ }^{25}$.

Whereas, in the Byzantine tradition the concept of hijab is seen as a means of controlling oneself from the lust that strikes. Men always see women from the side of sexuality, thus implying many practices of exploitation in women ${ }^{26}$. The views of Byzantine society are so in harmony with the Mutadha Mutahhari view, as described above. The view of Byzantine society is influenced by clashes and historical contacts with ancient Persian thought that resulted in Islamic nuances in tradition. On the other hand, the hijab in the view of the Byzantine tradition symbolizes the Christian doctrine of the human concept, as Brown describes in his research cited by Anisa Fitria in his research, "human idealism is resisting its desire to be unaffected by it"27. 
Author view, from the various meanings above can be seen that the concept of hijab in the philosophical view of Murtadha Mutahhari has parallels with other views. Explicitly, the concept of hijab in the view of Murtadha Mutahahari is something that separates (distance) between men and women. Hijab aims to avoid all acts or attitudes of exploitation of women who tend to deprive their honor and glory. Hijab in the view of Murtadha Mutahhari can be simplified as a barrier between men and women in association. This is in contrast to the views of millennial people who view hijab as a fashion that results in sexual harassment or action or practice. One of the factors causing different views is that there is no knowledge of why the hijab is applied. So, in the next discussion will be explained about the reasons a woman should close with the study of social, ethical, and economic approaches.

\section{The Reason for Hijab}

Hijab practice has historically existed before Islam, as in ancient India and ancient Iranian society. The practice of hijab in ancient Indian and Iranian societies was more closed than the practice of the Arabs at that time ${ }^{28}$. Thus, Islam comes with various rules to reconstruct the understanding of Arab society in relation to the practice of hijab ${ }^{29}$. There are three basic reasons for the practice of hijab applied to the previous society, namely economic, social and ethical reasons. These three reasons are viewed as early history of the application of hijab. Murtadha Mutahhari discusses these three reasons based on Islamic values through a philosophical approach $^{30}$. It aims to know the meaning of hijab practice and to criticize the view that Islam restricts women's freedom ${ }^{31}$.

\section{The Economic Reason}

Economic reasons are one of the prevailing reasons, the hijab concept for the previous society - including Islam and the tradition of society before the millennial era. Bertrand Russell mentions there are four phases in this discussion, the communal (pre-historical) phase, the ownership phase, the rebellion phase, and the phase of equality. The first phase in his view has a connection with the act of sexuality, a woman is seen as a slave and a means to serve the needs (lust) of men. Women's rights are limited in this period, thus implying a partriarchy (view that explains that men are the sole holders of power in nature $)^{32}$. This view in the first phase indicates a second 
phase in the economic reason is the ownership phase. The ownership phase is the longest phase ever recorded by historians. On the other hand, this phase is also marked by the patriarchal movement. A movement depicting a woman must be subject to male rule, all women's rights are removed and restricted. This action raises the existence of a third phase, the phase of rebellion ${ }^{33}$.

The revolt phase flourished in the 19th century marked by the presence of the feminist movement. This movement demands women's rights to be returned and calls for equality between men and women so that all acts of women's exploitation are abolished, these movements appear in several Muslim countries and western countries, such as Al-jazair marked by the National Liberation Front (FLN) ) who called for al-jazair women's rights against French colonists, the United States is characterized by the movement of black women, Indonesia is characterized by the emancipation of women, and so on. The implications of this movement present a fourth phase called the phase of equality ${ }^{34}$.

Bertrand Russell misunderstood the application of the hijab concept. Murtadha Mutahhari argues that Russell and his group have confirmed that the hijab is related to the patriarchy shown by the female recruitment process. Men hire a woman to be employed for the benefit of men. The benefiting women and put them behind the curtain (hijab) with the aim of limiting all spaces of their activities, except serving men $^{35}$. It also explains the emergence of hijab as a process of exploitation by men against women. This view is questionable, is it true that the presence of hijab as a process of exploiting women's existence?

Explicitly, the view was denied by Murtadha Mutahhari. The application of hijab in Islamic discourse is not the case. In Islamic studies, the application of men as absolute rulers to women's economy is not true. Women have the right to do things by their will and desire. On the other hand, women have the right to refuse the work that is ordered and a man should not impose $\mathrm{it}^{36}$. As for the process of transactions (the process of renting women to men), a woman has the right to negotiate the wages and work they will be doing. A woman has the right to refuse, in the absence of any gain they gain in the negotiation process ${ }^{37}$.

Hijab in the view of Islam is not a limiting attitude to the existence of women, but the hijab in the Islamic view is to limit the attitude of exploitation of women's existence. Limiting the attitude of exploitation puts a honor to the existence of women, as explained by Jawadi Amuli in the book Women in the Mirror of Majesty and Beauty, translated by Ahmad Muhdor, that 
Islam is not a religion that places men as absolute rulers against women. Islam sees men and women as one reality, not based on the gender they possess, but based on the created being. So there is no limit or attitude to master each other in the perspective of Islam ${ }^{38}$.

Thus, the economic reason in the western view represented by Bertrand Russell is not something that should be accepted for granted. Murtadha Mutahhari contend the view that Russell's conclusions are incompatible with the hijab practice that teaches Islam. However, it is important to note that the economic reason in Russell's view is not totally rejected by Murtadha Mutahhari, he views that the exploitative attitude of men as one of the reasons applied by hijab (barrier or distance) between the two.

\section{The Social Reason}

One of the fundamental reasons for the practice of hijab for the ancients was that there was no security for women. Before the existence of various rules of tribal law and Islam, women always get crime from various parties ${ }^{39}$. In the past, people who had the power could master whatever it wanted. In fact, the aristocrats must conceal their jewels to avoid any form of evil ${ }^{40}$.

Overcoming this problem, the former community led by priests and kings formed traditions and ideas called hijab. Will Durant in History of Civilization explains that ancient Iranian society restricts the relationship of men and women (hijab) with the aim of protecting women from various sexual harassment attitudes ${ }^{41}$. So, women get security guarantees in the ancient Iranian tradition. Durant's view was reinforced by Imam Khomeini in one of his sermons in 1979, "Women have rights and obligations in the Islamic Republic of Iran because women have an important role in achieving the present and future revolutions by educating revolutionaries (young generation) and the government of the Iranian Republic responsibility to keep them ". Imam Khomeini's expression describes Iranian society from antiquity until now always puts women in special positions ${ }^{42}$.

In his philosophical view, Murtadha Mutahhari explains that the application of hijab in a social perspective is a form of protection for women from various sexual harassment attitudes. However, hijab in social view should be applied by mutual agreement. So as to form a peaceful society. On the other hand, society places women in dignity and honor position. Thus, Mutadha Mutahhari's view can be applied to the issues and thinking of the millennial society which views hijab as a fashion issue. This certainly can't be justified, if everyone sees hijab as fashion, then the meaning of 
hijab is not seen as a limitation of men and women, but as a medium in luring the opposite $\operatorname{sex}^{43}$. Therefore, it is necessary to attempt to instill this discussion in a millennial woman.

\section{The Ethical Reason}

The other reason for the implementation of hijab for the past is the moral problem. the problem of moral about relate to characters influenced by the selfishness of men in dominating and dominating women in order to exclusively exploit for themselves ${ }^{44}$. Greed wants to dominate and dominate thoroughly resulting in the adoption of hijab practices for women. A man can hold his lust for wealth, but a man can't hold the passion of his sexuality toward women ${ }^{45}$. Basically, it is known that greed is not a good thing in a human being. Greed leads people to a limited point until they are unable to refrain from their own deeds, which makes mankind increasingly immoral ${ }^{46}$.

Murtadha Mutahhari explains that passion is a natural instinct given by God to be human to protect society, not personally. That means, given to preserve future generations and descendants. However, men have enjoyed satisfaction, causing them to increase and act and are immoral. The more people enjoy it, the more immoral they are. On the contrary, the more controlled, the more morally they are. controlling sexuality will shape human nature in human beings ${ }^{47}$. In this case, one must control bad habits, such as jealousy, greed, and so on. This process will provide moral values in it, they can protect and keep women from the attitude of exploitation and maintain the purity of women ${ }^{48}$.

The goodness of man is to build relationships between people and maintain the purity of himself and society. Only moral people do not allow cruel acts and actions against women. In fact, very little is found that men maintain their moral and actions. This is also a problem for society first. So, the concept of hijab applies, to overcome this problem. Hijab provides restrictions and distance for the actions of men against women, the implications of reducing harassment for women ${ }^{49}$. On the other hand, the veil restores the presence of passion as an explanation mentioned by Murtadha Mutahhari.

\section{The Real Visage of Hijab}

In the previous discussion has been explained about the reasons for the practice of hijab for the community first, so that in this discussion will 
explain the essence of hijab. In his philosophical view, Murtadha Mutahhari offers four essences of hijab studied based on Islamic rules, including psychological tranquility, strengthening family relationships, a strong society, and the glory and honor of women ${ }^{50}$. These four essences, implies discussion of the benefits provided in hijab practice, both psychologically, socially, and others studied through a philosophical approach. On the other hand, the discussion of the nature of hijab in the philosophical view of Murtadha Mutahhari aims to criticize the western view represented by Bertrand Russell who views that Islamic hijab limits the will of women. ${ }^{51}$.

\section{Psyschological Tranquility}

If there are no rules that limit the relationship between men and women, then the results of exploitation for women. Such actions and deeds are based on desires that describe the thirst of one's soul and an insatiable need. Because, the instinct of human sexuality is very strong and entrenched $^{52}$. Although some people argue, like hedonism follows the lust of indicating humans have defeated it. However, the nature of greed will continue to influence one's thinking, like a fire that burns wood to ashes. The exact analogy in describing a man's passion for a woman ${ }^{53}$.

On the other hand, history notes that prior to the existence of hijab various movements of violence against women became one of the fact of the absence of peace of soul felt by the previous society, such as the existence of patriarchal movement. All such violence is based on a man's love of lust, a man will commit violence to fulfill his wish. this also becomes an important consideration in practicing hijab on this issue ${ }^{54}$.

Murtadha Mutahhari views that Islam as a religion of grace has paid special attention to this issue. Islam provides the rules of male and female associations with the aim of preserving purity and respect for the existence of both. As stated in sura an-Nur verses 30-31 that have been corrected in the previous discussion. The command Qs. An-Nur / 24: 30-31, an order to avoid the evil view that is forbidden by Islam $^{55}$. Therefore, the underlying problem is based on physical contact between men and women. Islam as a religion of grace teaches its followers to avoid everything that is honesty that causes the birth of Tranquility lahiriyah and batiniyah ${ }^{56}$. Tranquility lahiriyah including the sense of security that people use in the form of activity, without fear-based that affects the lives of men and women. Meanwhile, Tranquility batiniyah including perfection of one's soul is closer to $\operatorname{God}^{57}$. 
The view of Murtadha Mutahhari was confirmed by Jawadi Amuli that Islam has put women in the best possible position. Considering all the rules with the aim of the absence of discrimination felt by women, even the sacrifices of the muslims, such as Sayyidah Khadijah and Sayyidah Fatimah became an example in building relationships with women. In the view of Islam there is no gender issue between men and women, both are equal before God. So every human must compete closer to Him based on the strength and calm of a strong soul. In building the strength and tranquility of the human soul must build a hijab or keep the distance of both, so avoid the act that can weaken the soul ${ }^{58}$.

\section{Strengthen the Relationship of Husband and Wife}

Basically the practice of hijab aims to avoid all forms of disgraceful acts that are forbidden by Islam. However, it should be noted that the practice of hijab in the philosophical view of Murtadha Mutahhari aims to maintain harmony and strengthen the relationship between husband and wife ${ }^{59}$. One form of harmony is a man and woman is forbidden to look and show body shape, except on the husband or wife. So, avoid the attitude of jealousy and infidelity that can destroy the household. In essence, the practice of hijab gives pleasure and enjoyment of husband and wife relationships and limits the things that are beyond it.

But young men now, especially in the western world, see marriage as the end of pleasure. Caused, the emergence of limits in free sexual behavior. Marriage will limit the pleasure of lust to only one subject (wife or husband), otherwise those who follow promiscuity can make sexual pleasure of any object. On the other hand, a group of individuals who follow sexual behavior freely view that marriage is merely to defend the offspring, so that humans who have such thoughts are humans have no purpose in life in the future ${ }^{60}$.

The difference between societies dealing with their sexuality through marriage bonds and the communities involved in sexuality through association, is that free sex communities will see that marriage is the beginning of the ban on free sex. Conversely, those who follow and believe in sex should be limited by husband and wife relationships that marriage is the beginning of pleasure and the beginning of creating a prosperous household. Anything that can strengthen of husband-wife relationship must be maintained, while the things that cause a weak husbander relationship must be resisted ${ }^{61}$. 
In addition, an important consideration is that free sex acts affect human thinking, especially young men and women. Those who follow free sex acts will delay marriage and form a family, before their passions are fully met. They will marry after losing their spirits and waves in their youth. In this condition, marriage is not seen as a duty, but a mere formality in building public relations ${ }^{62}$. Avoiding the emergence of such thoughts, the concept of hijab is applied to strengthen the bonds of husbands and wives so as to form a harmonious family relationship in building a household.

\section{Strengthen of the Society}

In the previous discussion has been discussed about the real visage of hijab in a husband-wife relationship. This discussion will depart from a view that states that marriage simply produces offspring alone. This statement is certainly not true and rejected. Hijab essentially maintains the sanctity and honor of both men and women. The purity of man and woman creates a peaceful and peaceful environment. Maintaining each other's holiness and protecting from the disgraceful acts forbidden by religion implies the strengthen of society ${ }^{63}$. On the one hand, this view contradicts the various western views represented by Bertrand Russell who see that hijab curb the existence of women and kill the creativity of a woman in a social frame.

The problem of women's sanctity is an important issue in the social order, especially in building inter-community welfare. The society of ignorance can be regarded as a bad society, namely the existence of monopoly and exploitation by women ${ }^{64}$. The destruction of the society system is determined by the existence of women. Imam Khoemini in his sermon said that the role of women gives much influence to people's lives ${ }^{65}$. If a woman gives a negative problem, then the condition of society is also damaged. Shame, If a woman gives something positive, then give positive conditions for the life of the surrounding community. From that answer, a question arises, how can one give a positive meaning to people's lives?

These questions are often asked in discussing and assessing the hijab issue. in essence, a woman must break away from the deplorable acts prohibited by Islam. In the view of Murtadha Mutahhari, hijab is the media or limiting tool of various disgraceful acts. Women must make a distance or a barrier between them and something to be reproached. Something despicable always leads a person to despise, thus implying a negative impact $^{66}$. As for, hijab always avoids the disgraceful conduct, resulting in a 
positive impact. Thus, the hijab in itself (the essence) has a positive nuance which always gives good impact to human life, especially society.

\section{The Glory and Honor of Women}

It has previously been pointed out that the real visage of hijab affects the relations of society through the existence of women. The effects of hijab are not limited to the social context, but about the honor and glory of women. The practice of hijab aims to protect women from various attitudes that distress their dignity and honor. In the previous chapter, especially the discussion of the reasons for applying the hijab has been explained that hijab protects women against all sexual practices. Men always seek pleasure and pleasure to satisfy their desires, while women always show and show off the beauty of their bodies, thus reflecting disgraceful deeds ${ }^{67}$.

Hijab limits the lusts of both, so that all acts of reproach can be avoided. The restriction of hijab does not limit women to existence, but rather puts the dignity and glory of women as well as possible. As explained by Asghar Ali Engineer in his work entitled The Rights of Women in Islam, Islam puts women different from other religions. Women in the view of Islam is to have honor and glory. Honor and glory not as a mother, but have perfection in its form $^{68}$. Asghar Ali interpreted the perfection of being transcendent, so as to have a relationship with the Divine essence. The practice of hijab attempts to reflect the minds of men to protect and respect the side of the perfection of women.

Asghar Ali's explanation reinforces the philosophical outlook of Murtadha Mutahhari on the role of the hijab in safeguarding and protecting women's honor. In general, Mutahhari's view seeks to explain that the meaning as well as its role and function is to maintain that perfection. Every man can hold his lust for wealth and power, but not all men can withstand sexual appetite. Therefore, the existence of a man and woman can suppress his passions, then realize life safely within the social frame, strengthen the family, and bring peace of the soul. Thus, the process of maintaining the satisfaction and glory of women is the process of achieving perfection in the human psyche ${ }^{69}$.

\section{Implication of Hijab Murtadha Mutahhari}

In the previous discussion has described some views Murtadha Mutahhari, especially the problem of reasons and the essence of the 
implementation of hijab for the community first. In this discussion will be discussed about the implications or involvement of the concept of hijab Murtadha Mutahhari on hijab issues in the millennial era. One of the hijab issues that developed in millennial society, is the existence of thoughts and views of hijab as fashion or fashion. In fact, the views and thoughts of modern society are based on the absence of knowledge on the concept of hijab. So it needs an explanation of the reasons and the nature of the concept of hijab for the millennial community.

On the basically, the application of hijab aims to limit the association of men and women. Such restrictions seek to avoid free sex acts between the two. Implementation of hijab in the perspective of the community first experienced significant distortion, hijab is seen as a fashion in millennial society thinking. The view of hijab as a fashion indicates the acts and deeds of sexuality. Fashion always directs a person into the center of attention and views of the opposite sex, consequently the act of exploitation of women in the millennial era can not be avoided. This is also reinforced by data collected by Komnas Perempuan, as quoted by sindonews.com, that there has been a significant increase in cases of sexual violence and domestic violence every year. Based on the records of Komnas Perempuan in 2016 found 245,548 cases of sexual harassment. Then, in 2017 there was an increase of 259,150 cases of sexual violence and abuse against women handled by Religious Courts and Service Partnering Agencies spread over 34 provinces $^{70}$.

In addition, the data of the Indonesian Child Protection Commission (KPAI) is another proof that women of all ages, both young and old get violence and exploitative acts over the past three years. As with KPAI data, in 2015 there were 218 cases of child abuse. While in 2016, KPAI noted there were 120 cases of sexual violence. Then in 2017, there were 116 cases $^{71}$.

From both data, it is known that high levels of violence and sexual harassment of women result in loss of security in the social frame. In the previous discussion, explained that one of the reasons hijab is practiced for women is to protect it from sexual acts and actions. However, the application of hijab in this era is declining. The practice of hijab does not have a role in protecting and protecting women, this is due to differences of opinion between the past and present society.

On the other hand, increased sexual abuse for women describes the lack of honor and glory of women in the view of men today. Women are seen as the fulfillment of men's lust. In fact, the glory and honor of women is like 
a leader. If a leader is damaged or not trust in running his leadership, it creates destruction and disgrace for people's lives.

Of the various problems, the concept of hijab in the philosophical view of Murtadha Mutahhari be a solution in overcoming the problems that hit the people of today. The concept of the hijab must be reconstructed with the aim of removing bad thoughts and views on the concept of hijab. Mutahhari sees the hijab as a social barrier between men and women. The meaning of the limits in Mutahhari's view is not material, but immaterial. Meaning of hijab is immaterial based on the object to be limited, namely lust. Lust restriction means removing the despicable acts forbidden by Islam ${ }^{72}$. Islam restricts all the pleasures and pleasures of the lust, except the husband and wife bonds. In effect, Islam harmonizes and encourages husbands and wives to build households, and avoids violence, jealousy, and divorce within the family.

On tbe basically, the concept of hijab in the view of Murtadha Mutahhari not only limits human desire. However, giving honor and glory to women. Islam sees women as perfect beings, because they are created by perfect piety. Perfection possessed by women must be maintained and protected, thus providing a sense of security in women. When a woman gets her honor, it creates a solid and peaceful society. Women are free to do their social activities, whether berekonomi, educated, religion, and so forth without any fear based.

If the offer of Murtadha Mutahhari is applied in millennial society, it creates a peaceful and peaceful life. One does not find any abuse against women, thus lowering the level of violence and sexual abuse today. Decreasing levels of violence and abuse are characterized by honoring and respecting women ${ }^{73}$. The attitude of respecting and glorifying women creates a sense of security for women, resulting in the calm of the soul for every human being. Psychological tranquility is the essence of the hijab in the view of Murtadha Mutahhari. The man who controls his desires is the man who perfected him. The limitation of desire in the view of Mutahhari is a process of perfection in the human soul, before the soul leaves the body ${ }^{74}$.

Thus, it is known that the concept of hijab in the view of Murtadha Mutahhari needs to be applied in millennial society. With a variety of considerations based on aspects and problems that hit millennial society. Hijab needs to be reconstructed through the philosophical approach of Mutahhari with the aim of creating a harmonious life among humans, establishing a sense of passion in building a home, putting the glory of women as it should be, and improving the soul of millennial society, 
especially closer to God. The application of the hijab concept in Murtadha Mutahhari's view restores the rails or places the hijab on its function, as well as the essence, meaning, and reason for applying the hijab.

\section{Conclusion}

The hijab concept in the millennial view is viewed and understood as fashion. Understanding is based on the absence of knowledge on the essence, meaning, and the reasons for applying the concept of hijab. As a result, the hijab has no function and role in the millennial century. Problems arise in the midst of millennial societies, such as sexual harassment of women to violence that causes material death. Both attitudes describe the lack of security for women in the social sphere in the millennial era. Thus, hinting the lack of harmony between communities that led to the weak social order. On the one hand, violence and sexual abuse explain the absence of respect for and glorification of women.

The lack of public relations and the lack of respect for women is a matter to be solved. In solving the problem requires a solution regarding the concept of hijab that is appropriate to the nature and the reasons for the implementation of hijab. The concept of hijab in the view of Murtadha Mutahhari is a solution in overcoming the problems in the millennial era. Murtadha Mutahhari view hijab as a boundary or barrier between men and women. The boundaries understood by Mutahhari are not material, but immaterial. Therefore, the restricted object is lust.

$\mathrm{Hijab}$ in the view of Mutahhari restricts the free sex of men and women, but gives pleasure to the bonds of husbands and wives. Giving pleasure aims to harmonize the ties of both, thus avoiding jealousy and violence in building a home. If every family builds households based on harmony, it affirms people's lives. However, please note that limiting the passions, harmonizing family ties, and the solidity of the public order describe the tranquility of the human soul. Psychological tranquility is a process towards perfection in the view of Murtadha Mutahhari. Thus, the concept of hijab in the view of Murtadha Mutahhari must be applied in the life of the millennial society in order to overcome all the problems that occur. 


\section{Endnotes}

1 Qoidud Duwal Konsep Jilbab dalam Hukum Islam: Studi Pemikiran Husain Muhammad (Yogjakarta: Universitas Islam Negeri Sunan Kalijaga, 2009), page. 3

2 Murtaza Mutahhari, On the Islamic Hijab (Tehran: International Publishing, 2008), page. 4

3 Umar Sidiq, Diskursus Makna Jilbab dalam Surat al-Ahzab: Menurut Ibnu Kathir dan Quraish Shihab (Ponorogo: Sekolah Tinggi Agama Islam Ponorogo, 2012), page. 170.

4 Umar Sidiq, Diskursus Makna Jilbab dalam Surat al-Ahzab: Menurut Ibnu Kathir dan Quraish Shihab, page. 177

5 Fedwa El-Guindi, Jilbab antara Kesalehan, Kesopanan, dan Perlawanan ( Jakarta: Serambi Ilmu Semesta,2013), page. 49

$6 \quad$ Fedwa El-Guindi, Jilbab antara Kesalehan, Kesopanan, dan Perlawanan, page. 49

$7 \quad$ Fedwa El-Guindi, Jilbab antara Kesalehan, Kesopanan, dan Perlawanan, page. 47

8 Nur Khaerat Sidang, Fenomena Trend Fashion Jilbab dalam Keputusan Pembelian Hijab ( Makassar: Universitas Islam Negeri Alauddin Makassar, 2016), page. 5

9 Khairun Nisa, Trend Hijab terhadap Konsep Diri Hijabers: Komunitas Hijab Medan (Medan: Universitas Muhammadiyah Sumatra Utara, 2017), page. 106

10 Ade Nur Istiani, Konstruksi Hijab Fashion bagi Moslem Fashion Blogger (Lampung: Universitas Lampung, 2015), page. 49

11 Dewi Lestari, Konsep Hijab Menurut Murtadha Mutahhari (Yogjakarta: Universitas Islam Negeri Sunan Kalijaga, 2015), page. 6

12 Atabik dan Ahmad Zuhdi Muhdlor, Kamus Kontemporer Arab-Indonesia (Yogjakarta: Multi Karya Grafika, 2015), page. 739

13 Murtaza Mutahhari, On the Islamic Hijab, page. 12

14 Naila Rahmatika Alif, Eksistensi Hijab Menurut Murtadha Mutahhari (Surabaya: Universitas Islam Negeri Sunan Ampel, 2012), page. 21

15 Ahmad Suhendra, Kontestasi Identitas Melalui Pergeseran Interpretasi Hijab dan Jilbab dalam al-Qur'an, PALASTREN VI, vol. 6, no.1 (2013), page. 3

16 Badi'atul Husna, Identitas Sosial Penggunaan Hijab dalam Kelompok Mahasiswa Inkafa, Kelompok Rohis Universitas Brawijaya dan Komunitas Hijaber Malang (Malang: Universitas Islam Negeri Maulana Malik Ibrahim, 2015), page. 22

17 Murtaza Mutahhari, On the Islamic Hijab, page. 12

18 Murtaza Mutahhari, On the Islamic Hijab, page. 13

19 Murtaza Mutahhari, On the Islamic Hijab, page. 15

20 Forum Kajian Kitab Kuning, Kembang Setaman Perkawinan (Jakarta: Kompas Media Nusantara, 2009), page. 272

21 Murtaza Mutahhari, On the Islamic Hijab, page. 14

22 Murtaza Mutahhari, On the Islamic Hijab, page. 15

23 Jawadi Amuli, Keindahan dan Keagungan Perempuan translated by Ahmad Muhdor and tim (Jakarta: Sadra Press, 2010), page. 66

24 Fedwa El-Guindi, Jilbab antara Kesalehan, Kesopanan, dan Perlawanan, page. 50-51

25 Arvind Sharma, Today's Woman in The World Religions (New York: State University of New York Press, 2008), page. 305

26 Fedwa El-Guindi, Jilbab antara Kesalehan, Kesopanan, dan Perlawanan, page. 53

27 Anis Safitri, Jilbab dalam Pandangan Fadwa El-Guindi: Telaah atas Buku "Veil: Modesty, Privacy, and Resistance” (Surabaya: Universitas Islam Negeri Sunan Ampel, 2017), hal. 78

28 Murtadha Mutahhari, Teologi dan Falsafah Hijab, translated by tim Rausyan Fikr (Yogjakarta: Rausyan Fikr, 2013), page. 43

29 Arvind Sharma, Today's Woman in The World Religions, page. 312

30 Murtaza Mutahhari, On the Islamic Hijab, page. 25

31 Murtaza Mutahhari, On the Islamic Hijab, page.26

32 Murtaza Mutahhari, On the Islamic Hijab, page. 39

33 Bertrand Russell, Mortal and Others: American Essay (London: Routledge, 2010), page 61.

34 Bertrand Russell, Mortal and Others: American Essay, page 24.

35 Murtaza Mutahhari, On the Islamic Hijab, page. 40 
36 Murtaza Mutahhari, On the Islamic Hijab, page. 40

37 Murtaza Mutahhari, On the Islamic Hijab, page. 41

38 Jawadi Amuli, Keindahan dan Keagungan Perempuan, translated by Ahmad Muhdor and tim, page. 75

39 Murtaza Mutahhari, On the Islamic Hijab, page. 41

40 Delia Cortese dan Simonetta Calderini, Women and The Fatimids in The World of Islam (Edinburgh: Edinburgh University Press, 2009), page. 73

41 Murtadha Mutahhari, Wanita dan Hijab, translated by Nashib Mustafa (Jakarta: Lentera, 2008), page. 52

42 Imam Khomeini, The Position of Women, diterjemahkan oleh Behrooz Arezoo (Tehran: The Institut for Compilation and Publication of Imam Khomeini's Works, 2009), page. 65

43 Murtadha Mutahhari, Wanita dan Hijab, translated by Nashib Mustafa, page. 80

44 Murtadha Mutahhari, Wanita dan Hijab, translated by Nashib Mustafa, page. 69

45 Murtadha Mutahhari, Wanita dan Hijab, translated by Nashib Mustafa, page. 70

46 Bertrand Russell, Mortals and Others, page. 109

47 Murtaza Mutahhari, On the Islamic Hijab, page. 42

48 Agustin Hanapi, Peran Perempuan dalam Islam (Banda Aceh: Universitas Islam Negeri Ar-Raniry, 2015), page. 16

49 Murtaza Mutahhari, On the Islamic Hijab, page. 44

50 Murtaza Mutahhari, The Islamic Modest Dress, 2009, page. 10

51 Murtadha Mutahhari, Wanita dan Hijab , translated by Nashib Mustafa, page. 97

52 Janeth Radicliffe Richards, Speptical The Feminist: A Philosophy Enquiry (London: Routledge,2009), page.98

53 Betrand Russell, Sejarah Filsafat Barat, translated by Sigit Jatmiko and Agung Prihantoro (Yogjakarta: Pustaka Pelajar, 2016), page. 309

54 Fatimah Mernissi, Wanita di dalam Islam (Bandung: Pustaka, 2014), page. 109

55 Murtaza Mutahhari, The Islamic Modest Dress, 2009, page. 73

56 Fedwa El-Guindi, Jilbab antara Kesalehan, Kesopanan, dan Perlawanan, page. 53

57 Kholid Al-Walid, Perjalanan Jiwa Menuju Akhirat: Filsafat Eskatologi Mulla Sadra (Jakarta: Sadra Press, 2012), page. 225

58 Jawadi Amuli, Keindahan dan Keagungan Perempuan, translated by Ahmad Muhdor and tim, page. 132-133

59 Murtaza Mutahhari, The Islamic Modest Dress, 2009, page. 14

60 Murtaza Mutahhari, The Islamic Modest Dress, 2009, page 14-15

61 Murtaza Mutahhari, The Islamic Modest Dress, 2009, page. 16

62 Murtaza Mutahhari, The Islamic Modest Dress, 2009, page. 17

63 Fatima Mernissi, Wanita di dalam Islam, 229

64 Asghar Ali Engineer, The Rights Of Women in Islam (New Delhi: New Dawn Press Group, 2010), page. 24

65 Imam Khomeini, The Position of Women, Translated by Behrooz Arezoo, page. 66

66 Ruth Groehout dan Maryam Bower, Philosophy Feminism and Faith (Amerika Serikat: Indiana University Press, 2009), page. 227

67 Murtaza Mutahhari, The Islamic Modest Dress, 2009, page. 55

68 Asghar Ali Engineer, The Rights Of Women in Islam, page. 172

69 Murtaza Mutahhari, The Islamic Modest Dress, 2009, page. 43

70 MAF,Kasus Kekerasan Seksual Perempuan dan Anak Masih Tinggi, https://nasional. sindonews.com/read/1250835/13/kasus-kekerasan-seksual-perempuan-dan-anakmasih-tinggi-1508732434, diakses pada 26 April 2018, pada pukul 10:30 WIB.

71 Davit Setyawan, Tahun 2017, KPAI Temukan 116 Kasus Kekerasan Seksual terhadap Anak, http://www/kpai.go.id/berita/tahun-2017-kpai-temukan-116-kasuskekerasan-seksual-terhadap-anak, diakses pada 26 April 2018, pada pukul 10:45 WIB.

72 Murtaza Mutahhari, The Islamic Modest Dress, 2009, page. 54

73 Murtaza Mutahhari, The Islamic Modest Dress, 2009, hal. 84

74 Murtaza Mutahhari, The Islamic Modest Dress, 2009, page. 74 


\section{REFERENCE}

Alif, Rahmatika, Naila. Eksistensi Hijab Menurut Murtadha Mutahhari. Surabaya: Universitas Islam Negeri Sunan Ampel,2012.

Al-Walid, Kholid. Perjalanan Jiwa Menuju Akhirat: Filsafat Ekskatologi Mulla Sadra. Jakarta: Sadra Press, 2012.

Amuli, Jawadi. Keindahan dan Keagungan Perempuan. Translated by Ahmad Muhdor and tim. Jakarta: Sadra Press, 2010.

Atabik dan Muhdlor, Zuhdi, Ahmad. Kamus Kontemporer Arab-Indonesia. Yogjakarta: Multi Karya Grafika, 2015.

Cortese Delia dan Calderini Simonetta. Women and The Fatimids in The World of Islam. Edinburgh: Edinburgh University Press, 2009.

Duwal, Qoidud. Konsep Jilbab dalam Hukum Islam: Studi Pemikiran Husain Muhammad. Yogjakarta: Universitas Islam Negeri Sunan Kalijaga, 2009.

El-Guidi, Fedwa. Jilbab antara Kesalehan, Kesopanan, dan Perlawanan. Jakarta: Serambi Ilmu Semesta, 20013.

Engineer, Ali, Asghar. The Rights Of Women in Islam. New Delhi: New Dawn Press Group, 2010.

Forum Kajian Kitab Kuning. Kembang Setaman Perkawinan. Jakarta: Kompas Media Nusantara, 2009.

Groehout Ruth dan Maryam Bower, Philosophy Feminism and Faith. Amerika Serikat: Indiana University Press, 2009.

Hanapi, Agustin. Peran Perempuan dalam Islam. Banda Aceh: Universitas Islam Negeri Ar-Raniry, 2015.

Husna, Badi'atul. Identitas Sosial Penggunaan Hijab dalam Kelompok Mahasiswa Inkafa, Kelompok Rohis Universitas Brawijaya dan Komunitas Hijaber Malang. Malang: Universitas Islam Negeri Maulana Malik Ibrahim, 2015.

Imam Khomeini. The Position of Women. Translated by Behrooz Arezoo. Tehran: The Institut for Compilation and Publication of Imam Khomeini's Works, 2009.

Istiani, Nur, Ade. Konstruksi Hijab Fashion bagi Moslem Blogger. Lampung: Universitas Lampung, 2015. 
Khairun, Nisa. Trend Hijab terhadap Konsep Diri Hijabers: Komunitas Hijab Medan. Medan: Universitas Muhammadiyah Sumatra Utara, 2017.

Lestari, Dewi. Konsep Hijab Menurut Murtadha Mutahhari. Yogjakarta: Universitas Islam Negeri Sunan Kalijaga, 2015.

MAF. Kasus Kekerasan Seksual Perempuan dan Anak Masih. Tinggi,https: / nasional.sindonews.com/read/1250835/13/kasus-kekerasanseksual-perempuan-dan-anak-masih-tinggi-1508732434. Diakses pada 26 April 2018, pada pukul 10:30 WIB.

Marnisi, Fatima. Wanita di dalam Islam. Bandung: Pustaka, 1994.

Mutahhari, Murtadha. Teologi dan Falsafah Hijab. Translated by Tim Rausyan Fikr. Yogjakarta: Rausyan Fikr, 2013.

Mutahhari, Murtadha. Wanita dan Hijab. Translated by Nashib Mustafa. Jakarta: Lentera, 2008.

Mutahhari, Murtaza. On the Islamic Hijab. Tehran: International Publishing, 2009.

Mutahhari, Murtaza. The Islamic Modesty Dress, 2009.

Richard, Radicliffe, Janet. Sceptical The Feminist: A Philosophy Enquiry. London: Routledge, 2009.

Russell, Bertrand. Mortal and Others: American Essay. London: Routledge,2010.

Russell, Bertrand. Sejarah Filsafat Barat. Translated by Sigit Jatmiko and Agung Prihantoro. Yogjakarta: Pustaka Pelajar, 2016.

Safitri, Anisa. Jilbab dalam Pandangan Fedwa El-Guindi: Telaah atas Buku "Veil: Modesty, Privacy, and Resistence". Surabaya: Universitas Islam Negeri Sunan Ampel, 2017.

Setyawan, Davit. Tahun 2017, KPAI Temukan 116 Kasus Kekerasan Seksual terhadap Anak.http://www/kpai.go.id/berita/tahun-2017kpai-temukan-116-kasus-kekerasan-seksual-terhadap-anak. Diakses pada 26 April 2018, pada pukul 10:45 WIB.

Sharma, Arvind. Today's Woman in The World Religions. New York: State University of New York Pres, 2008.

Sidang, Khaerat, Nur. Fenomena Trend Fashion Jilbab dalam Keputusan Pembelian Hijab. Makassar: Universitas Islam Negeri Alauddin Makassar, 2016. 
Sidiq, Umar. Diskursus Makna Jilbab dalam Surat al-Ahzab: Menurut Ibnu Katsir dan Quraish Shihab. Ponorogo: Sekolah Tinggi Agama Islam Ponorogo, 2012.

Suhendra, Ahmad. Kontestasi Identitas melalui Pergeseran Interpretasi Hijab dan Jilbab dalam Al-Qur'an. PALASTREN VI, no.1 (2013). 